\title{
Olumlu ve Olumsuz Manası ile Siyasal Katılım Türlerinin İncelenmesi
}

\author{
DOI: 10.26466/opus.509050 \\ *
}

\section{Abdullah Aydın}

* Dr. Öğr. Üyesi Hatay Mustafa Kemal Üniversitesi İ̈BF, Uluslararası İlişkiler Bölümü

E-Posta: aaydin@mku.edu.tr

\author{
Antakya/Hatay
}

ORCID:0000-0002-1785-4999

\begin{abstract}
Öz
Her siyasal rejimde bireylerin toplum içerisinde işgal ettikleri yer kadar devlet ve dolayısıyla da siyaset içerisinde de bir yeri vardır. Özellikle demokratik rejimlerin varlık sebebi her bir bireyin yaşadıklar ülkenin yönetiminde söz sahibi olabilmesi ülküsüdür. Bu çerçevede demokrasiler tüm bireyleri siyasal alana doğru itmeyi hedeflemektedir. Bu durum isteyerek veya istemeyerek siyasal katılımı meydana getirir. Siyasal katılım günümüz siyaset bilimi için çok kritik bir kavramdır. Zira siyasal katılım günümüz demokrasinin kalitesini gösteren en temel öğedir. Bir ülkedeki demokrasinin işlerliği katılımın să̆lı̆̆ı ile ölçülebilmektedir. Nitekim katılımın niceliğinden çok niteliği önemlidir. Zira katılım her manası ile olumlu bir süreç doğurmamaktadır. Dolayısıyla bir ülkenin demokrasiyi içselleştirme durumu siyasal katılımın ne kadar olumlu boyutları ile yaşanabildiği ile doğru orantılıdır. Bu çalışmada ilk olarak siyasal katılım kavramı ele alınmış akabinde, siyasal katılım türlerinin neler olduğu tespit edilmeye çalışılmış ve bu inceleme olumlu ve olumsuz boyutları ile değerlendirilmiştir. Ayrıca Türkiye özelinde bu durumlara nasıl rastlandı̆̆̆ üzerine bilgiler verilmeye çalışılmıştır.
\end{abstract}

Anahtar Kelimeler: Demokrasi, Siyasal Katılım, Klientalizm, Tokenizm, Depolitizasyon, Türk Demokrasisinde Katılim 


\title{
Analysis of Political Participation Types With Positive And Negative Meaning
}

\begin{abstract}
In every political regime, individuals have a place in the state and society as well as in politics. In particular, the reason for the existence of democratic regimes is that each individual can have a say in the administration of the country in which they live. In this context, democracies aim to push all individuals towards the political sphere. This creates willing or unintentional political participation. Political participation is a very critical concept for today's political science. Because political participation is the most fundamental element of the quality of today's democracy. The functioning of democracy in a country can be measured by the health of participation. As a matter of fact, quality rather than quantity is important. Because participation does not create a positive process with every sense. As a matter of fact, a country's internalization of democracy is directly proportional to the positive dimensions of political participation. In this study, firstly, the concept of political participation was discussed and then the type of political participation was tried to be determined and this study was evaluated with its positive and negative dimensions. It has also tried to provide information on how these situations is encountered in particular Turkey.
\end{abstract}

Keywords: Democracy, Political Participation, Klientalism, Tokenism, Depolitization, Participation in Turkish Democracy 


\section{Giriş}

Bireylerin toplum işgal ettikleri yerleri kişi-toplum-devlet (otorite) üçgenindeki ilişkiler ağı belirlemeye başlaması bu noktada yöneten-yönetilen ilişkisinin nasıl olacağı sorusuna sebep olmuştur. Bu bağlamda yöneticiler için günümüzün popüler kalıbı 5N1K soruları sürekli sorulmuştur. Açık bir ifade ile kimin, neyi, nasıl, neden, nerden, ne zaman yöneteceği sorunsalı gündemin en önemli noktasıdır. $\mathrm{Bu}$ sorular ise meşruiyet arayışları insanlığın her döneminde önemini korumasına neden olmuştur. Çünkü yöneten kesim yönetilenlerin yani toplum ve daha özelde bireyin bizatihi itaatini sağlamak için, iktidarlarının bir şekilde meşru zemine oturması gerektiğinin farkında olmuşlar. Bu yüzden meşruiyeti sağlamak için yüzyıllar boyunca değişik yollar uygulanmaya çalışılmıştır.

Bu manada yöneten-yönetilen ilişkisi, neredeyse tüm yönleriyle toplumsal hayatın üzerine inşa edildiği ana ilişki biçimidir. Bireyler sosyal manada birebir olarak oluşturulan dostluk, arkadaşlık ve benzeri gibi ilişkileri bir kenara koyup sadece salt bir birey, yani belli başlı rolleri olan insanlar olarak kurulan bütün ilişkilerinin içerisinde ya yönetici veya yönetilen olarak bulunurlar. Bilim insanlarının birçoğu bu temel ilişki ve onun ana kaynağı üzerine kafa yormuş; kendi yaşadıkları dönemde ve bölgelerdeki yöneten-yönetilen ilişkilerini idrak etme çabası, beraberinde, bu ilişkinin nasıl ortaya çıtığını izah etme, keşfetme gayretini de oluşturmuştur (Bravo, 2006, s.123).

Demokrasi hem masraflı hem de zaman alan bir rejimdir. Demokrasinin kendine has yapısı yüzünden özellikle siyasetle aktif uğraşan insanlar tarafından hızlı bir şekilde geçiştirilmeye veya belli pazarlıklarla en temel kazanım olan iktidara götüren oyun alınması sağlanması hedeflenmektedir. Bu bağlamda birçok yönteme başvurulmaktadır. Nitekim bu yollar ve sonuçları bir takım katılım türleri başlığı altında toplanmıştır. Bu çalışmada katılım türleri ortaya konularak onlar hakkında genel bilgiler eşliğinde değerlendirme yapılarak olumlu olumsuz yönleri ortaya konulmuştur.

Türkiye'deki durum özelinde ele alındığında demokrasi kavramının gün be gün yerleşmesi veya kurumsallaşması durumu söz konusu olduğunu söylemek yanlış olmaz. Ancak demokrasinin tüm aygitlarının 
yerleşmeye başlaması katılımın olumlu yanları kadar olumsuz boyutlarını da devreye sokmaktadır.

Zira demokrasi ile ilgili temel başarı daha çok almak merkezli bir hal alması özellikle seçim merkezli bir rejim olarak anlaşılması durumu demokrasinin bir çıkmazı olarak değerlendirilebilir. Öyle ki demokrasi bu çerçevede farklı şekilde anlaşılmaya da (çoğunluk despotizmi, demokratur, demokratik oligarşi vb.) başlamıştır. Bu çerçevede çalışmanın boyutu çerçevesinde değinilmiş olan olumlu ve olumsuz katılım yollarının Türkiye yansımaları önem arz etmektedir.

\section{Siyasal Katılım Kavramının İncelenmesi}

Temelde sosyal, siyasal, yönetsel vb. faaliyetlere iştirak manasına gelen siyasal katılım, sosyal ve siyasal kurum veya kuruluşların almış olduğu kararlardan etkilenen (veya etkilenme ihtimali olan) kişi veya grupların bu kararların alınmasına (alınması sürecine) katılmasını anlatan bir kavramdır (Yayla, 2003, s.93). Ancak siyasal katılım bu kısa tanımda belirtildiği kadar açık ve üzerinde mutabakat sağlanmış bir kavram değildir.

Katılım, kişi ya da bir grubun karar alma sürecine en alt seviyede sesini duyurması en üst seviyede ise kararı alması arasında geniş bir alanda gerçekleşen bir manada, kişinin bir karar alma sürecine olan müspet veya menfi katkısını ifade ettiğinden birçok farklı anlamda ele alınması doğaldır. Katılım kavramının daha iyi anlaşılması için 2004 yılında Galler hükümeti tarafından yapılan katılım kavramı açıklama yarışmasında kazanan tanımlamaya göz atmakta fayda vardır: Katılım bir kişinin doğrularının kendisini ilgilendiren ve etkileyecek olan bir karar alma sürecine dâhil olması, yani çok sesliliğin ve seçimin olması demektir (Participationworkerswales, 2018).

Demokrasinin olmazsa olmazı veya en azından asgari şartı olarak görülen katılım (Dahl, 2001, s.39) dar anlamda, sadece seçimlere katılım olarak kısıtlanabilir (Çukurçayır, 2011: 43). Yani bu tanımlamada siyasal katılım sadece tekil davranışlarla gerçekleşir, bireyin devletle olan ilişkisi interaktif bir süreç izlemez (Higgs vd., 2008, s.596). Başka bir ifade ile bu durum en alt düzeyde katılımın ifadesidir.

Daha kapsamlı bir perspektif ile ele aldığımızda katılım, bir ülke veya bölgede toplumu oluşturan vatandaşların siyasal sistemle kurduğu 
ilişkilerin bütününü kapsayan bir kavram olarak karşımıza çıkmaktadır. $\mathrm{Bu}$ ilişkiler siyasal olayları takip etme ve bilgi alma, haber toplama ve inceleme, siyasal alanda herhangi bir faaliyette bulunma, oy verme, bir siyasi aksiyona destek veya tepki verme, yönetim için seçimlerde aday olma ve siyasal karar mekanizmalarında yer alma gibi farklı şekil ve boyutlarda kendisini göstermektedir (Gökçimen, 2008, s.7).

Geniş anlamda siyasal katılım, hem yerelde hem de genelde oluşturulan siyasal alanlarda yapılan faaliyetler ile vatandaşların farklı şekillerde yönetimi elinde bulunduran veya siyasal manada iktidarda bulunan kesim üzerinde baskı oluşturmaları, doğrudan veya dolaylı bir şekilde siyasal sürece katılarak çeşitli etkiler oluşturmaları şeklinde ifade edilebilir (Güldiken, 1996, s.31).

Başka bir tanımda ise katılım, yönetimin yaptığ 1 tercihleri ve yönetim ile ilgili kararları etkilemek amacıyla karar alma ve uygulama süreçlerine müdahil olma durumunu ifade etmektedir (Higgs vd., 2008, s.596). Benzer bir şekilde Verba, Nie ve Converse $(1989$, s.1) katılımı "vatandaşların karar vericilerinin seçimi ve onların yapmış oldukları eylem ve işleri doğrudan veya dolaylı bir şekilde etkileme maksadıyla giriştikleri yasal eylemler" olarak izah etmektedir (Belli, 2016, s.47). Yukarıda belirtildiği üzere katılım bir davranış, eylem veya çalışma olarak ele alınmıştır. $\mathrm{Bu}$ anlayışı biraz daha ileri götüren bazı yazarlar bireylerin siyaset ve siyaset yapanların ortaya çıkardığı siyasalar karşısındaki tutumlarını, ilgi ve düşüncelerinin varlığını da katılım kapsamı içerisinde değerlendirmişlerdir (Daver, 1993: 203; Kapani, 2007, s.144).

Öztekin'in (2011, s.251) ifadesi ile katılım, düzenli aralıklarla yapılan seçimlerde oy vermekle beraber yalnızca bununla sinırlı kalmayarak, aynı zamanda her ne şekilde ortaya çıarsa çıksın bir siyasal karar karşısında ortaya çıkan ilgi seviyesi ve bu ilginin neticesi şeklinde de tanımlanmıştır (Belli ve Aydın, 2012, s.136). Bu yüzden siyasal katılımın iki ana mecrada ortaya çıktığı söylenebilir; birincisi toplumu oluşturan bireylerin, toplum üzerinde bir güce iktidarı kullanacak şekilde yerel ve ulusal düzeydeki yetki aktarımında yani devleti idare edecek yöneticilerin seçiminde, ikincisi ise yöneten kesimin ortaya koyduğu kararlara ve karar alma süreçlerine halkın dâhil edilmesinde veya halkın dâhil olmasındadır (Dursun, 2010, s.234). 
Siyasal katılmanın sabit ve belli bir biçimi ve düzeyinin olmaması doğaldır. Bu yüzden birbirinden farklı biçim ve düzeyde gerçekleşmektedir. Siyasal katılım ani ve tek hamlelik bir durum olmadığı için bir süreci (inişli ve çıkışlı bir seyir izleyebilir) ifade etmektedir. Bu sürecin değişken olmasını sağlayan temel etkenler katılımcların nitelikleri ve katılım biçimleridir. Ayrıca katılım çoğu zaman, katılma sağlayacak bireyin fikri ve zihni ön değerlendirme sürecinin ardından gerçekleşir. Dolayısıyla bireyin düşünsel bir hazırlığının olmadığı katılımlar sakattır (Çukurçayır, 2012, s.216).

\section{Siyasal Katılım Türleri}

Siyasal Katılımı türleri bağlamında ele aldığımızda, birey-grup-toplum üçgenin bir incelemesinin yapılması gerekmektedir. Bu yapılan incelemelerde siyasal katılımı etkileyen faktörler ve sonucunda ortaya çıkan durumun oluşturduğu farklı katılım yolları bulunmaktadır. Bu katılım türleri ortaya çıkma çeşitleri ve düzeyleri aynı şekilde ortaya çıkarttıkları durum ve ektiler bağlamında değerlendirilmiş ve tasnif edilmiştir. Nitekim siyasal katılım türleri bu çerçevede değerlendiğinde demokratik kabiliyet açısında olumlu ve olumsuz olmak üzere iki farklı başlık altında toplanabilir. Olumlu sayılabilecek katılım türleri oydaşma, danışma, işbirliği ve bütünleşme başlıklarında toplanırken klientalizm, tokenizm ve depolitizasyon da siyasal katılımın olumsuz türleri olarak değerlendirilmiştir. Bu kısmında söz konusu siyasal katılım türleri ele alınmıştır.

\section{Oydaşma}

Türkçede öz Türkçe olan "Uzlaşı" veya yabancı kökenli olan Konsensüs kelimeleri ile de ifade edilen oydaşma, literatüre "Toplum Sözleşmesi" kavramı ile beraber kazandırılmıştır. Nitekim Rousseau, oydaşmayı toplumun kalbi olarak tanımlamaktadır. Rousseau bu tanımlamayı yaparken "özgür olarak doğan bir birey nasıl oluyor da farklı yöntemler ile zincire vuruluyor?" sorusunu sorarak başlamıştır. İşte bu noktada meşruiyetin temellerini tartışarak soruya cevap aramıştır. Oydaşma kavramının şekillenmesi ya da daha iddialı bir ifade ile neşvü nema bulmasının 
temelinde, Rousseau'nun oydaşma kavramı gibi birçok kavramı kapsayan "toplum sözleşmesi" teorisi yatmaktadır. Bu bağlamda oydaşma, bireylerin ve grupların, siyasal manada toplumsal değerler ile ilgili ortak fikir geliştirmesi olarak ifade edilmektedir. Toplumun her kademesini içine alan, bütünleştirici ve kapsayıcı bir yapıyı ifade eden oydaşma, kamuoyunun ortak değer sistemi olarak anlaşlabilir. Yani toplumu oluşturan tüm katmanların kabul edebileceği bir çerçeve ile çizilmiş, belli sınırları olan siyasal değerlerin, siyasal alanda paydaşlar tarafından ortak paylaşılması oydaşma olarak anlaşılmalıdır (Graham, 1970, s.81).

Demokratik bir yapıda tüm siyasi kurumların ve hatta siyasetle uğraşan herkesin temel sorumluluklarının başında, özgürlükler ile otorite arasındaki dengeyi sağlamak çabası gelmektedir. Ne özgürlüklerin sınırları otoritenin kıskacına alınarak daraltılmalı ne de özgürlükler kamu genel düzenini sarsacak hale gelmelidir. Eğer bu durum sağlanır ise demokrasi uygulanabilir hale gelir ve ideal ortamda bireyler ve gruplar arasında kamu yararını gözetecek bir oydaşma ortaya çıkar (Göztepe, 2016: 9). Bir diğer anlatım ile oydaşma siyasal tüm kurumların meşriyetini sağlama noktasında önem arz etmektedir. Zira toplumun en azından kahir ekseriyeti tarafından kabul görmemiş veya görememiş bir siyasal kurumun varlığını sürdürmesi mümkün değildir (Aydın ve Belli: 2015: 402403).

Türkiye bağlamında oydaşma kavramı değerlendirildiğinde genç bir demokratik kültüre sahip olmasına ragmen gün be gün daha demokratik hale gelmek için inişli çıkışlı bir grafik çizildiği gözlemlenmektedir. Bu çerçevede özellikle askeri bürokrasinin ülke üzerindeki tahakkümünün kırılması önemli bir durum olarak karışımıza çıkmaktadır. İlk demokratik seçime müteakip gerçekleşen her on yıllık süreçte bir askeri müdehale ve halkın kendi seçmiş oldukları yerine başka otoritelere prim vermesi veya en azından ses çıkarmaması bu müdahalelerin yapılasını kolaylaştırması açısından önem arz etmektedir. Ancak 15 temmuz süreci işi farklı bir boyuta taşıdığını söylemek mümkündür. Halk askeri bürokrasiye veya en azıdan bir kısmının demokratik kurumları askıya alma çabasına karşı direniş göstermiştir. Oydaşma kavramı bağlamında değerlendirildiğinde her ne kadar her kesim tarafından farklı boyutları ile eleşitirilse de demokrasi ve halk egemenliği ortak payda olarak ele alınabilir. 


\section{Danışma}

Siyasal katılımın bir türü olan danışma, halkın kendisini bizzat etkileyecek bir konu/karar ile ilgili süreç başlamadan veya başladıktan sonra görüş bildirmesidir. Danışma mekanizması ile hedeflenen, halkın fikrinin alınması ve yapılacak işin ortaya çıkmasını hızlandırıcı ve sonuçlarını belirleyici hamlelerin yapılmasıdır. Bunun yapılmasında ön plana çıkan en önemli kavram şeffaflıktır. Halka danışılan ve onlardan görüş istenen konular ile ilgili halka yeterince bilgi verilip verilmediği, danışmanın salahiyetini belirleyen en önemli hususların başında gelmektedir. Yapılacak projelere, çıkartılacak yasalara halkın bir şekilde katılmasını sağlayan bu mekanizma, istişare, bilgi ve görüş alışverişi gibi yollarla katılımın oluşmasını sağlar (Sosyal, 1968, s. 37; Brodie vd. , 2009, s.21).

Amerika ve İngiltere'de uzun süredir uygulanan “Danışma” yönteminin Osmanlı Devleti'nde de çeşitli benzer uygulamalarının varlığ bilinmektedir. Sened-i İttifak ile ortaya çıkan "Meclis-i Ahkam-1 Adliye", "Dar-1 Şûra-yı Bab-1 Âli" ve “Dar-1 Şûra-yı Askeri" gibi kuruluşlar padişah otoritesi ile beraber bir mana ifade eden ve onu sınırlamasa da danışma işlevi gören kuruluşlar olarak karşımıza çıkmaktadır (Soysal, 1969, s.2526). Günümüzde ise özellikle kangren olmuş belli sorunlar için "Akil Adamlar Heyetleri" nin ve "Halk Danışma Kurulları" nın oluşuturulması bu katılım türüne Türkiye'den örnek olarak gösterilebilir. Kritik konular ile ilgili oluşturulması ve sorunlara derinlemesine çözüm bulmadan çok yüzeysel kalması özellikle Türkiye açısından işlerliğini sorgulatmıştır.

\section{İşbirliği}

Siyasal katılım gerçekleştiren her toplumsal kademe doğal olarak bir diğeri ile iletişim ve ilişki içerisindedir. Bu durum yönetim ile olan münasebetlerde de farklı düzeylerde geçerlidir. Yöneten kesim ile katılan kesimler veya sadece katılan kesimlerin arasında tesis edilen işbirliği ile belli konularla ilgili ortak çalışma sağlanır. Bu durum alınan kararların kabullenilmesine, bireylerin iş ve uygulamaları içselleştirmesine, toplumsal ve grupsal aidiyetin artmasına katkı sağlar. Diğer yandan siyasal alanda gerçekleşen işbirlikleri aracılığıyla toplumun her kesiminin kendine yakın görüşler etrafında konsolide olma fırsatı bulunacaktır. Bu 
birliktelik tek potada erimek şeklinde gerçekleşebileceği gibi geçici, kısıtll, sinırlı ve iyi niyetsiz de olabilir (Brodie vd., 2009, s.20). Bu kavramın Türkiye bağlamında uygulamasını açacak olursak, yerel ve merkezi düzeydeki sivil toplum kuruluşlarının ve diğer siyasal alanda faaliyet gösterme öncelikli faaliyet yapmayan tüm örgütlerin belli konular bağlamında alana çekilmesi şekilde anlaşılabilir. Bu durum diretk olarak siyasi çekişmenin konusu olmayan ortak konular ile ilgili çalışmaları yürütmek şekilinde değerlendirilebilir. Örneğin bir siyasal partinin milletvekilinin, vekili olduğu ilin sorunlar veya tanitılması ile ilgili olarak il tanıtım birimleri, yerel yönetimler, yerel sivil toplum kuruluşları ve halka bir faaliyet yürütmesi olarak değerlendirilebilir. Nitekim bu bağlamda Ankara ve İstanbul gibi merkez illerde "İl Tanıtım Günleri" düzenlenmesinde ve faaliyetilerin siyasal alanda da ses getirmesinde o ilin vekillerinin katkısı büyüktür.

\section{Bütünleşme}

Demokrasinin en temel özelliklerinden biri de tüm toplumu bir bütün ve tam olarak değerlendirmesidir. Bu çerçevede değerlendirildiğinde bütünleşme; toplumun dezavantajlı bireyler de dâhil olmak üzere tümünün siyasal alandaki katılımını ifade etmektedir. Yani bütünleşme tüm toplumu bir bütün gibi görüp birbirinden ayırmamadır. Zira tarihsel süreç incelendiğinde, siyasal rejim demokrasi bile olsa siyasal alanda ekonomik, sosyal ve irksal nedenlerle bazı gruplar etkili olamamıştır. Bu gruplar kadın, göçmen, engelli, köle, hasta, yaşlı, genç ve benzeri şeklinde siralanabilir.

Siyasal alanda oluşacak bir durumun salahiyeti toplumun her kesimine yayılıp yayılmadığg ile doğru orantılıdır. Bu cihette her ne sebeple olursa olsun toplumsal dezavantajlı kesimlerin hepsinin siyasal alanda mevcut olması gerekmektedir. Bunu sağlayacak toplumsal ve devlete ait mekanizmalardır (Unece, 2018). Diğer bir anlatım ile demokrasi ve katılımın sağlığını denetlemek diğer konularda olduğu gibi devletin ve diğer bağımsız kurumların temel vazifesi olmalıdır.

Türkiye özelinde değerlendirildiğinde bütünleşme yanlış algınan bir katılım türüdür. Bir takım siyasal partilerin yerel ve merkezi seçimlerde belirledikleri adaylara kadın, engelli veya genç kotası koyması bunun bir 
göstergesi olarak karşımıza çıkar. Niyet olarak yapılmak istenen olumlu bir tutum gibi değerlendirilse de sonuçta bu grupları bir ayrımcılığa tekrar maruz bırakılmış olunur. Bütünleşme sosyal boyutları ile ele alınması gerekmektedir. Bir bireyin dezavantajlı duruma getiren tüm engellerin ortadan kalkması siyasal alanda da etkisini gösterek halkın bir bütün olarak değerlendirilmesine neden olacaktır. Yani bir partinin kadın, engelli veya genç adayının veya seçilmişinin kotalar dahilinde çok olması olumlu bir durumdur. Ancak asıl olması gereken ülkedeki temsil adaletinin her kesim için dengeli bir şekilde sağlanmasıdır.

\section{Tokenizm}

Daha iyi bir siyasal katılım olsun diye yapılan çalışmalar toplumun her alanına ulaşmayı hedeflemektedir. Fakat siyasal alana girmek için, istesin ya da istemesin insanların veya grupların önüne konan engeller onları siyasal alandan uzaklaştırmaktadır.

Bireylerin ve grupların siyasal alandan uzaklaşma konusunda istekli olmadığ1 düşünülür. Fakat bilgi alamayan, yapılanlara etki etmeyen/edemeyen, siyasal alana yabancılaşan kişiler ve gruplar toplumda ciddi bir yer kaplamaktadır. Nitekim toplumun her kesimini kapsayan bir şekilde davranma çabası, birey ve gruplar için bir manada formaliteden bir "siyasete katıldırma" neticesi doğurmuştur. Temel amaç siyaseti dizayn edenlerin, toplum zihninde siyasal bir sistem olarak "demokrasinin iyi işlediğinin düşünülmesini sağlamak "tır. Bir diğer mana ile dinsel, ırksal, cinsel ve sınıfsal olarak toplumda ortaya çıkan ayrımcılıkları kamufle etme çabasıdır (Morrisona ve Dearden, 2013, s.3).

Türkiye bağlamında tokenizm çokça rastlanan bir durum olmasına ragmen üzeri örtülü bir kavram veya kişilerin kendilerini bu şekilde tanımlamadıkları için iyi anlaşılamamıştır. Seçmenin parti taassubu veya anlık kararları sonucu vermis oldukları oyların peşine düşmemesi olarak da değerlendirlebilir. Kişi katılımın en temel öğesi olan oy verme davranışını göstermiştir. Ancak seçtiği kişinin yaptığı iş ile ilgili takip yapmamaktadır. Bu durum özellikle karizmatik parti liderlerinin olduğu dönemlerde daha çok rastlanan bir durumdur. Yerelde ise kişiye sorulmuş gibi yapılarak veya bir mahallede halk günü düzenleyerek sorunlar dinlendiği ve yerel katılımın sağlandığı gibi bir art niyetli yaklaşım 
geliştirilir. Ancak yereldeki her birey olmasa da çoğunluğa bir şekilde ulaşılmadığı sürece yapılan köy- mahalle veya semt toplantıları, halk günleri, halk masası çalışmları, internet paylaşımları ancak tokenizim olacaktır. Nitekim özellikle yerel dijital katılıma önem gösterdiğini her seferinde vurgulayan belediye başkanlarının troll hesaplar kullanarak tokenizme çanak tuttuğu bilinmektedir.

\section{Klientalizm}

Patronaj ilişkisi olarak da tanımlanan klientalizm, sadece katılım alanında değil, sosyal ve ekonomik alanda da kullanılan bir kavramdır. Genellikle birbirleri ile eşit ekonomik veya siyasal statüde olmayan birey, grup, hatta toplumların birbirlerine etki etmek için yaptıkları menfi hamleleri ifade eder (Britannica, 2018).

Kayırmacılık bağlamında da ele alınan klientalizm Orta Çağ Avrupası'nda lortlar ve feodal beylerle köylüler arasındaki veya antik Roma'da vatandaşlar ve uşaklarının arasındaki ilişkilerde örneğini bulan ve kendisini ifade eden bir tanımlamadır. Modern devletlerin ortaya çıkmasıyla birlikte, yani 19. yüzyılın sonundan itibaren, patron-yanaşma ilişkileri iki farklı şekle dönüştürülmüştür. Bir yandan, her rejimin kurumları içindeki farklı güruhlar çeşitli yöntemlerle ele geçirilmekte ve siyasal alanda etkileri yönetilmektedir. Öte yandan, toplumsal güruhlar birer müşteri gibi ele alınmakta ve her ne kadar demokratik bir zorunluluk gibi gözükse de kurumların verimliliğinin önündeki engeller olarak farz edilmekte ve bu yüzden yönetimin işlerine karışılmayacak birkaç sus payı verilmektedir. Bu bağlamda klientalizm, siyasetçilerin uzun vadeli politikalar gerçekleştirmek yerine, kendisine oy veren birey veya grupları müşteri gibi görüp ilişki geliştirmesi, (satın) aldığı oy karşılığında, güruhun yararına bir politika veya hizmette bulunması anlamına gelmektedir (Hopkin, 2006, s.2).

Katılım gerçekleştiren güruh çoğu zaman bu duruma razı olur. Her ne kadar siyasal etik açısında sorun teşkil etse dahi, kendisine demokrasi veya diğer rejimler içerisinde güç sağlayan her yönetimi (oy verme, kamuoyu oluşturma ve diğer siyasal davranışlar) kendi menfaati yararına kullanmak için reel bir birey gibi davranması beklenir. 
Klientalizm Türkiye'de özellikle kırsal kesimde, büyük ailelerin yaşadığı yerlede ve feodalitenin varlığını devam ettiği yerlerde hala etkisini devam ettirmektedir. Bu durum sadece 3-5 bin nüfuslu yerlerde orta hatta büyük sayılabilinecek yerlerde de geçerlidir.

Katılımın en temel aracı olan "oy"un para ile satıldığı bir duruma çok spesesifik örnekler dişında Türkiye'nin demokrasi kültürü içinde çokça rastlanan bir durum değildir. Ancak satılmaya eş değer olacak belli makamların verilmesi çokça rastlanan bir durumdur. Belli bir mensubiyetten gelen kişilere kontenjanlar ayrılarak makamlar pay edilmesi söz konusu olmaktadır. Örneğin, belli bir belediye için başkan bir aileden çıkıyorsa diğer büyük ailenin adayı ya bir dönem sonra belediyeyi alıyor, yani sırayla başkanlık yapıyorlar veya bir aile başkanlığı alırsa öbür aile yardımcığılı̆̆ını alıyor.

Klientalizmin tamamen olumsuz olması durumu söz konusu da değildir. Günümüz seçim sisteminde dar bölge gibi daha demokratik bir yöntem tercih edilmemektedir. Ancak ilin sosyokültürel yapısı, partileri mecbur etmektedir. Yani örneğin 10 milletvekili olan, nüfusu 1 milyon olan, (il merkezi 300 bin, ikinci büyük ilçe 250 bin üçüncü büyük ilçe 200 bin olduğu) bir tabloda, kliantalist kaygıları da içinde barındıran nedenler yüzünden her parti ilk sıraya il merkezinden, ikinci sıraya ikinci büyük ilçeden, üçüncü sıraya ise diğer ilçeden adaylar koyma yoluna gitmektedir. Yani birinci siraya il merkezinden bir aday koymazsak bize oy vermezler durumu söz konusu olabilmektedir. Bu durum küçük sayılabilecek iller için geçerlidir, büyük illerde nüfusa doğru orantılı olarak milletvekili sayısı fazla olduğu için pek geçerli değildir.

\section{Depolitizasyon}

Depolitizasyon, kavram olarak bir grup, durum, eylem veya kurumun siyasal özelliğini kaybetmesi veya siyasal düzlemden uzaklaşması-uzaklaştırılması manasına gelmektedir (Tdk, 2018).

Depolitizasyon kavramı diğer bahsettiğimiz kavramlardan bir iki ana nokta ile ayrılmaktadır. Bu ayrımın ana noktası bazı bilim insanlarının depolitizasyonu, özellikle refah bağlamında iyi noktada olan ülkelerde 1950'li y1llarla beraber başlayan siyasetten soğuma durumunun kavramsallaşmış hali olarak yorumlamasındadır. Bu bağlamda Lipset 
"Political Man" isimli eserinin son bölümüne "İdeolojinin Sonu” adını vermiş ve özellikle batı dünyasının siyasal hayattan uzaklaşmasını nazara vermiştir (Lipset, 1960, s.402-420). Sosyal ve siyasal alandan beklentisi, kazandığı hakların yeterli gelmesi üzerine git gide azalan halkın artık siyaseti sıkıcı bulmasına neden olmuştur. Bunu İsveç'te yaşanan örnek üzerinden ele alan Lipset, İsveç siyasal gündeminin üç ana başlığının olduğunu, bunların; demir işçilerinin saat ücretleri, süt fiyatlarının seviyesi ve emekli aylıkları olduklarını belirtmektedir. Bu durum, batı dünyasının sanayi toplumuna evrimini tamamlaması ve bu evrim sırasinda yaşanan sıkıntıları aşması üzerine, en çok handikap oluşturan sosyal güvenlik konusunun da çözüme bağlanması ardından bu sebeplerin bir sonucu olarak gerçekleşmektedir.

Toplumun, kendisini tatmin edecek bir hayat standardına ulaşması ile siyasal sistemden beklentilerinin bitebildiği düşünülebilir. Siyasal alandan beklentisi bireysel menfaatler bağlaminda kalmayan birey, siyasal alandan soğumaya başlamaktadır (Himmelstrand, 1962, s.83-85). Nitekim Batı üzerinden ele alınan Depolitizasyon, istenilen siyasal taleplere karşılık bulunması ve stabil bir düzenin olduğu ülkelerde katılımın sıkıntıya girmesi ayrıca halkın siyasete mesafeli ve soğuk durmasına neden olması durumlarıyla ifade edilmektedir. Dolayısıyla depolitizasyon, yöneticilerin veya başka bir gurubun katılımı engellemesi ya da bilinçli bir siyasetten uzaklaştırma çabası değil, halkın kendisinin yaşadığı bir durumdur.

Depolitizasyon bir manada ekonomik gelişmişlik ve refah seviyesi ile alakalı bir durumudur. Dolayısıyla Türkiye'de ancak belli yerlerde rastlamak mümkündür. İstanbul ve Ankara'nın lüks semtlerinde seçimlerde oy kullanma oranın düşüklüğü de bu durumla alakalı olarak değerlendirlebilir. Ancak bu durum kısıtlıdır. Zira Türkiye'nin belli azınlığ1 dışında depolitize olacak refah seviyesine ulaşılamamıştır.

\section{Sonuç Yerine Siyasal Katılım Türleri Üzerine Bir genel Değerlendirme}

Günümüzün başat siyasal rejimi olan demokrasi için en kritik kavramların başında siyasal katılım gelmektedir. Siyasal katılım kavramının bu kadar önemsenmesinin altında yatan birçok neden vardır. Bunların en 
başında demokrasi deyince akla gelen ilk kavram olan seçimlerdir. Seçimler için en basit tanımlama halkın kendi kendini yönetmesi için (temsili demokrasi bağlamında) yönetici belirlemesi etkinliği şeklinde olduğu söylenebilir. Her ne kadar siyasal katılım kavramının bireylerin oy kullanma veya yönetime talip olma faaliyetlerine indirgenmesinin yanlış olduğu çalışmada çok kereler ifade edilmiş olsa da, bu değerlendirme bir takım güç grupları tarafından kabul görmekte ve bireyler sadece oy verme aygıtı veya bir istatistik gibi ele alınmaktadır. İşte bu bağlamda sadece siyasal katılımın değil nitelikli bir siyasal katılımın varlığının ancak demokrasinin kalitesini ortaya koyduğu realitesinin geniş çerçevede el alınması gerekmektedir. Bahsi geçen kaliteli bir siyasal katılım ise tüm bireylerin olabildiğince maksimum düzeyde farklı vasitalarla siyasete katılmasının sağlanmış olması demektedir. Bunu yaparken de farklı olumsuz ilişkiler ağ1 yani klientalizm ve tokenizm bağlamında katılmanın sağlanmamasına özen gösterilmelidir. Zira her ne kadar bu sürecin prosedürel olarak hiçbir sıkıntısı gözükmese de demokrasinin temel unsuru olan özgür birey kararlarının gerçekleşmemesi demokrasiye darbe vurmaktadır.

Demokrasi sadece patronaj ilişkileri veya katıldırma hilesi tehlikesi ile karşı karşıya değildir. Bu sorunlar genel itibariyle demokratik olarak gelişmemiş ülkelere has bir durum olduğu söylenebilir. Hatta yazın buna odaklı şekillenmiştir. Ancak siyasal katılımın demokratik gelişmişliği fazla olduğu düşünülen ülkelerde "siyasette soğuma" şeklinde olumsuz durumlara düştüğü görülmektedir. Batının butik sayılacak ülkeleri de dâhil olmak üzere siyasal alana yabancılaşma, uzaklaşma veya ilgisizleşme ciddi bir sorun olarak demokrasinin önünde durmaktadır.

Diğer bir açıdan ele alındığında ise güncel teknolojik gelişmeler ve küreselleşme sayesinde demokrasinin bir yeni aşamaya geçtiğini söylemek mümkündür. Artık siyasal alana katılım ve o alanda kendini göstermek daha kolaydır. Ancak bu durum katılımın olumsuz yönlerini önlemek veya azaltmaktan çok sadece katılım sağlayanların işini kolaylaştırdığı gün be gün daha çok hissedilmektedir. Diğer bir anlatım ile başta mobil teknolojiler olmak üzere ortaya çıkan yeni teknolojilerin demokrasinin yaşamış olduğu problemlere çözüm olacağı umudu boşa çıkmıştır. 
Türkiye perspektifinde bakıldığında, Türkiye Tanzimat'tan beri adım adım demokratikleşmektedir. Bu süreç Cumhuriyeti doğrumuştur. Cumhuriyet başlı başına yetmemiş zira ilk demokratik genel seçim 1950 yılında, ilk demokratik yerel seçim ise 1963 yılında yapılabilmiştir. Günden güne ilerleme kaydetse de Türk demokrasisi içinde bir çok eksiği de barındırmaktadır. Demokratik kurumların tam olarak işleyememesi ve demokrasini sadece oy ile kazanma veya kaybetme gibi algılama diğer katılım yollarının göz ardı edilmesine neden olmaktadır. Halkın her kademede katılımını mümkün kılacak yapılar Türkiye'de vardır. Çalışmada bu konular üzerinde gereken açıklamalar yapılmıştır. Ancak demokrasinin içselleşitirilmesi ve ileri seviyede yaşanılabilir hale gelinmesi gerekmektedir. Gelişmiş bir demokrasi kültürünün olmadığ 1 yerde tüm demokratik hakların olması katılımın olumsuz yollarını ortaya çıkartır ve katılım sağlanmış gibi gözükür. 
EXTENDED ABSTRACT

\title{
Analysis of Political Participation Types With Posi- tive And Negative Meaning
}

\author{
Abdullah Aydın \\ Hatay Mustafa Kemal University
}

In every political regime, individuals have a place in the state and society as well as in politics. In particular, the reason for the existence of democratic regimes is that each individual can have a say in the administration of the country in which they live. In this context, democracies aim to push all individuals towards the political sphere. This creates willing or unintentional political participation.

Political participation, meaning participation in social, political, managerial, etc. activities, is a concept that refers to the participation of people or groups who are affected by the decisions taken by social and political institutions or organizations (or are likely to be affected) to participate in these decisions (Yayla, 2003: 93). However, political participation is not as clear and agreed as it is stated in this brief definition.

It is natural that a person or a group should make a decision in a minimum level of decision-making and at the highest level the decision is taken in a wide range of terms. For a better understanding of the concept of participation, it is useful to take a look at the winning definition in the contest for participation in the concept of participation made by the Welsh government in 2004: Participation is the involvement of a person in a decision-making process that affects and influences him / herself, that is to say, a multitude and choice (Participationworkerswales, 2018).

When we consider the political participation in the context of the types, it is necessary to conduct a review of the individual-group-community triangle. In these examinations, the factors affecting political participation and the different ways of participation are the result. The types and levels of these types of participation were evaluated and classified in the same way as they revealed and their status. As a matter of fact, when the types of political participation are evaluated in this framework, it can be divided 
into two different headings as positive and negative in terms of democratic capability. The types of participation that can be considered positive are gathered under the headings of consensus, consultation, cooperation and integration. Klientalism, Tokenism and Depolitization are also considered as negative types of political participation. In this section, these types of political participation are discussed.

Political participation is one of the most critical concepts for democracy, the dominant political regime of our time. There are many reasons underlying this concept of political participation. The first thing that comes to mind when it comes to democracy is elections. The simplest definition for the elections can be said to be the self-governance of the people (in the context of representative democracy) as an activity of ruling. Although the concept of political participation is often misrepresented in reducing the number of individuals to voting or governing activities, this assessment is accepted by a number of power groups and individuals are treated only as voting devices or as a statistic. In this context, the reality of the existence of a qualified political participation, not only political participation, but the quality of democracy, needs to be taken into consideration in a wide framework. Such a high level of political participation is that all individuals should be able to participate in politics with as many different means as possible. In doing so, care should be taken not to ensure participation in the context of different negative relations network, ie, clientalism and tokenism. Because, although there is no procedural shortage of this process, the fact that free individual decisions, which are the basic elements of democracy, are not realized, is a blow to democracy.

Democracy is not only facing the danger of patronage or make involvement. These problems can be said to be a situation which is generally unique to democratically undeveloped countries. Even in the summer it has been shaped. However, it is observed that political participation in countries that are considered to be more democratic than others, has a negative effect on political cooling. The alienation, divergence or indifference to the political sphere, including the western countries of the West, stands before democracy as a serious problem.

In another aspect, it is possible to say that democracy has moved to a new stage thanks to current technological developments and globalization. It is now easier to participate in the political sphere and to show itself 
in the field. However, this situation is felt more and more on a day-to-day basis, rather than simply preventing or reducing the negative aspects of participation. In other words, the hope that new technologies, especially mobile technologies, will be the solution to the problems of democracy.

When viewed in the perspective of Turkey, Turkey is democratizing step by step since the Tanzimat period. Although it progresses day by day, it has many deficiencies in Turkish democracy. The fact that democratic institutions cannot function properly and that their democracy can only be won by winning or losing votes causes other ways of participation to be ignored. However, democracy needs to be internalized and become more livable. The existence of all democratic rights where there is no developed democratic culture reveals the negative ways of participation and the participation seems to be ensured.

\section{Kaynakça / References}

Aydın, A. ve Belli, A. (2015). Cumhurbaşkanlığı ve Meşruiyet Tartışmaları, Türkiye'de seçim sistemindeki değişim cumhurbaşkanlığı seçimi ve medya iletişim ve siyaset odakl incelemeler, (Ed.: Faruk Temel ve Onur Önürmen), Ankara: Nobel Yayınevi, s. 87-102.

Belli, A. ve Aydın, A. (2012). Yerel demokrasi ve katılım: kahramanmaraş ve hatay illerinin karşılaştırılması.II. Bölgesel Sorunlar Ve Türkiye Sempozyumu.

Belli, A. (2016). Türkiye'de kent konseylerinin işlevselliği önündeki sorunlar ve çözüm önerileri: Büyükşehir belediyeleri örneği. Yayınlanmamış Doktora Tezi, Sütçü İmam Üniversitesi, Kahramanmaraş.

Bravo, H. (2006). Yöneten-yönetilen ilişkisi/ çelişkisi. Felsefe ve Sosyal Bilimler Dergisi, 1, 123-144.

Brodie, E., Cowling, E.,Nissen, N., P., Angela E., Jochum, V. ve Warburton, D. (2009). Understanding Participation: A Literature Review, http://pathwaysthroughparticipation.org.uk/wp-content/uploads/ 2009/09/Pathways-literature-review-final-version.pdf, (Erişim Tarihi: 08.011.2018).

Çukurçayır, M. A. (2012). Siyasal katılma ve yerel demokrasi. Konya: Çizgi Kitabevi. 
Dahl, R. A. (2001). Demokrasi üzerine, (Çev.: Betül Kadığlu), Ankara: Phoenix Yayınevi.

Daver, B. (1993). Siyaset bilimine giriş. Ankara: Siyasal Kitabevi.

Dursun, D. (2010). Siyaset bilimi. İstanbul: Beta Yayınları.

Higgs, G., Berry, R., Kidner D., Langford, M. (2008). Using IT approaches to promote public participation in renewable energy planning: Prospects and challenges. Land Use Policy, 25(4), 596-607

http://www.tdk.gov.tr. (Erişim tarihi: 05.05.2018).

https://global.britannica.com/topic/election-political-science, (Erişim Tarihi: 08.06.2018).

http://www.participationworkerswales.org.uk, (Erişim Tarihi: 05.10.2018).

Graham, G. J. Jr (1970). Rousseau's concept of consensus. Political Science Quarterly, 85(1), 80- 98.

Gökçimen, S. (2008). Ülkemizde kadınların siyasal hayata katılım mücadelesi. Yasama Dergisi, 10, 5-59.

Göztepe, E. (2016). Çoğunlukçu demokrasi anlayışına karşı çoğulcu demokrasi modelleri normatif düzenleme olanakları ve bunun sinırlllı̆̆ üzerine bazı düşünceler, http://www.kamuhukukculari.org/upload/dosyalar/Cogunlukcu_Demorasi_Anlayisina_Karsi_Cogulcu_Demokrasi_Modelleri_1.pdf, (Erişim Tarihi: 12.07.2018).

Güldiken, N. (1996). Toplum bilimsel boyutuyla siyasal katılım. Sivas: Dilek Ofset Matbaacilik.

Hopkin, J. (2006). Concept analysis: Unpacking clientelism, governance and neoliberalism. Philadelphia, Panel Sunumu

Himmelstrand, U. (1962). A theoretical and empirical approach to depoliticization and political involvement. Acta Sociologica, 6(1/2), 83110.

Kapani, M. (2007). Politika bilimine giriş. Ankara: Bilgi Yayınevi.

Lipset, S. M. (1960). Political man the sociail bases of politics. New York: Doubleday \& Company, Inc.

Morrisona, C. ve Dearden, A. (2013). Beyond tokenistic participation: Using representational artefacts to enable meaningful public participation in health service design. Health Policy, www.elsevier.com/ locate/healthpol, (Erişim Tarihi: 31.01.2018). 
Nie, N. H., Verba, S. ve Converse, P. E. (1989). Siyasal katılma, kamuoyu ve oy verme davranışı, (Çev.: İlter Turan ve Tuncer Karamustafaoğlu), Ankara: Siyasi İlimler Türk Derneği Yayınları.

Öztekin, A. (2011). Siyaset bilimine giriş. Ankara: Siyasal Kitabevi Sosyal, M.(1968). Halkın yönetime etkisi. Ankara: TODAİE Yayınları. Sosyal, M. (1969). Anayasaya giriş. Ankara: A.Ü.S.B.F. Yayınları.

United Nations Economic Commission for Europe UNECE (2009). Policy Brief on Ageing, http://www.unece.org/ fileadmin/DAM/pau/_docs/age/2009/Policy_ briefs/4-Policybrief_Participation_Eng.pdf, (Erişim Tarihi: 31.12.2018).

Yayla, A.(2003). Siyasi düşünce sözlüğüu. Ankara: Liberte Yayınları.

\section{Kaynakça Bilgisi / Citation Information}

Aydın, A. (2019). Olumlu ve olumsuz manası ile siyasal katılım türlerinin incelenmesi. OPUS-Uluslararası Toplum Araştırmaları Dergisi, 10(17), 2119-2138. DOI: $10.26466 /$ opus.509050 